Хожило Ірина Іванівна доктор наук з державного управління, професор, професор кафедри державного управління та місцевого самоврядування Дніпропетровського регіонального інституту державного управління Національної академії державного управління при Президентові України, вул. Гоголя, 29, кімн. 314-316, м. Дніпро, 49044, тел.: (056) 794-58-23, e-mail: dneprzdrav1@ukr.net, https://orcid.org/0000-0001-8532-4108

Полякова Ольга Станіславівна доктор наук 3 державного управління, провідний науковий співробітник наукового відділу Наукового центру проблем виховання доброчесності та запобігання корупції у секторі безпеки та оборони Національного університету оборони України ім. І. Черняховського, проспект Повітрофлотський, 28, м. Київ, 03186, тел.: (044) 271-08-43, e-mail: BITEC@ukr.net, https://orcid.org/0000-0003-2251-7468

\title{
СУЧАСНИЙ СТАН ФУНКЦІОНУВАННЯ СИСТЕМИ ПРАВОВОЇ ОСВІТИ В УКРАЇНІ: ПУБЛІЧНО-УПРАВЛІНСЬКИЙ АСПЕКТ
}

Анотація. У статті проаналізовано сучасний стан функціонування та розвитку системи правової освіти в України, визначено кількісні та якісні зміни в iii структурних компонентах, 3'ясовано роль публічного управління в організації правоосвітньої діяльності.

3'ясовано, що в Україні функціонує цілісна система правової освіти, яка є складною системою із множиною взаємопов'язаних і взаємозалежних елементів. Ключову роль в організації правоосвітньої діяльності відіграють органи державної влади, які забезпечують функціонування і розвиток інституціональної мережі, де громадяни країни здобувають знання і навички з правової освіти.

Визначено, що здобуття правової освіти здійснюється шляхом формальної, неформальної й інформальної освіти та розраховано в першу чергу на молоде покоління. Наймасовішим є здобуття правових знань шляхом формальної освіти через існуючу мережу закладів освіти різних рівнів.

У загальному вигляді правова освіта складається 3 двох підсистем непрофесійної загальноправової та професійної юридичної (спеціально-правової) освіти. Також може розглядатися у широкому (набуття правових знань людиною від іiі народження та їх удосконалюється протягом усього життя) та у вузькому розумінні (здобуття особистістю юридичної освіти та присудження відповідної 
кваліфікації).

Сучасна система правової освіти має низку проблем, які потребують розв'язання на державному рівні, зокрема: непослідовність у розробленні та здійсненні освітньої політики щодо поширення правових знань серед населення; перегляд, уточнення та/або оновлення змісту правової освіти, програм, правових дисциплін; відсутність узгодження в питаннях упровадження навчальних програм (курсів) на всіх рівнях освіти для всіх вікових груп населення; відсутність системності в підготовці/перепідготовці педагогічних i науково-педагогічних кадрів, задіяних у поширенні правових знань; здійснення моніторингу якості та результатів надання правових знань; реформування юридичної вищої освіти та ін. Ключові слова: публічне управління освітою, правова освіта, формальна, неформальна та інформальна освіта, мережа закладів освіти.

Khozhylo Iryna Ivanivna Doctor of Public Administration, Professor, Professor of the Department of Public Administration and Local Self-government of Dnipropetrovsk Regional Institute of Public Administration National Academy of Public Administration under the President of Ukraine, Gogol St., 29, of. 314-316, Dnipro, 49044, tel.: (056) 794-58-23, e-mail: dneprzdrav1@ukr.net, https://orcid.org/0000-0001-8532-4108

Polyakova Olga Stanislavivna Doctor of Public Administration, Leading researcher at the Scientific Department of the Research Center for Integrity Education and Prevention of Corruption in the Security and Defense Sector of the National Defence University of Ukraine named after Ivan Chernyahovsky, Povitroflotskyi Ave., 28, Kyiv, 03186, tel.: (044) 271-08-43, e-mail: BITEC@ukr.net, https://orcid.org/00000003-2251-7468

\section{CURRENT STATE OF LEGAL EDUCATION SYSTEM FUNCTIONING IN UKRAINE: PUBLIC-MANAGEMENT ASPECT}

Abstract. The article analyzes the current state of functioning and development of the system of legal education in Ukraine, identifies quantitative and qualitative changes in its structural components, clarifies the role of public administration in the organization of legal education.

It was found that Ukraine has a holistic system of legal education, which is a complex system with many interconnected and interdependent elements. A key role in the organization of legal education is played by public authorities, which ensure the functioning and development of the institutional network, where citizens acquire knowledge and skills in legal education. 
It is determined that legal education is obtained through formal, non-formal and informal education and is designed primarily for the younger generation. The most widespread is the acquisition of legal knowledge through formal education through the existing network of educational institutions at various levels.

In general, legal education consists of two subsystems - non-professional general and professional legal (special legal) education. It can also be considered in a broad sense (the acquisition of legal knowledge by a person from birth and its improvement throughout life) and in a narrow sense (the acquisition of legal education by the individual and the award of appropriate qualifications).

The modern system of legal education has a number of problems that need to be addressed at the state level, including: inconsistency in the development and implementation of educational policy for the dissemination of legal knowledge among the population; revision, clarification and / or updating of the content of legal education programs, legal disciplines; lack of coordination in the implementation of curricula (courses) at all levels of education for all age groups; lack of systematic training / retraining of pedagogical and scientific-pedagogical staff involved in the dissemination of legal knowledge; monitoring the quality and results of providing legal knowledge; reform of legal higher education, etc.

Key words: public education management, legal education, formal, non-formal and informal education, network of educational institutions.

Постановка проблеми. 3 перших днів державної самостійності правова освіта в Україні є предметом посиленої уваги з боку владних структур, оскільки саме тоді країна стала на шлях радикальних змін усіх сфер суспільного життя, які продовжуються й досі. Сьогодні, як ніколи, країні потрібні громадяни з високим рівнем освіти, які спроможні реалізувати ці зміни, активні у правовому аспекті та які мають достатньо високий рівень правової свідомості й правової культури. В цьому контексті протягом усього періоду незалежності в країні йде процес вироблення нової більш ефективної моделі освіти, робиться спроба модернізації як всієї освітньої галузі, так і іï правової складової.

Аналіз останніх досліджень і публікацій. Гуманітарні аспекти державного управління, зокрема проблематика управління освітою, управління знаннями, а також проблема становлення та розвитку правової/правничої освіти та правового виховання $\epsilon$ предметом дослідження значної кількості як зарубіжних, так i українських науковців. Однак, поза увагою авторів залишається дослідження сучасного стану функціонування національної системи правової освіти, визначення проблем, що гальмують їі розвиток. Саме це й зумовило вибір теми дослідження.

Мета статті - визначити та проаналізувати сучасний стан функціонування та 
розвитку системи правової освіти в України, визначити кількісні та якісні зміни в iї структурних компонентах, з'ясувати роль публічного управління в організації правоосвітньої діяльності.

Виклад основного матеріалу. В 2001 р. в Україні була затверджена Національна програма правової освіти населення, мета якої полягає у «підвищенні загального рівня правової культури та вдосконалення системи правової освіти населення, набуття громадянами необхідного рівня правових знань, формування у них поваги до права» [0]. У документі визначаються основні завдання, напрями та заходи реалізації Програми.

На підставі розгляду змісту документа пропонуємо авторське бачення національної системи правової освіти (рис. 1).

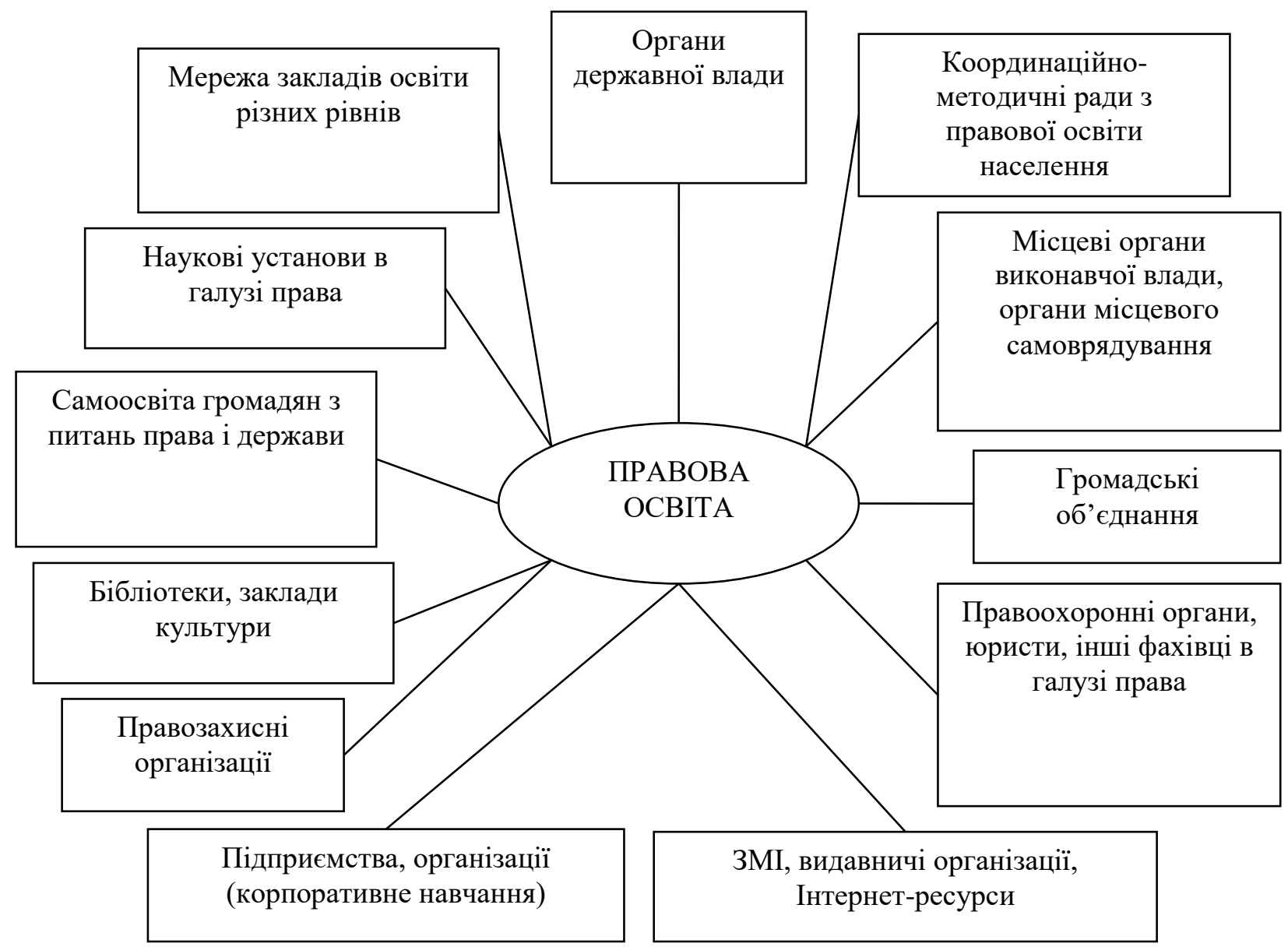

Рис. 1. Система правової освіти в України (розроблено авторами)

Представлена система правової освіти є складною, багатоаспектною, багатогранною, має значну кількість складових елементів, які в управлінській діяльності виступають одночасно і суб'єктами, і об'єктами, мають множинну взаємопов'язаність, взаємозалежність та взаємодіють між собою, з суспільством, суспільними групами й конкретною особистістю. Ключову роль у цій системі 
відіграють органи державної влади, які створюють сприятливі умови для здобуття громадянами знань і навичок з правової освіти та забезпечують функціонування всієї правоосвітньої системи (сформовані концептуальні, правові, організаційні, фінансово-економічні, науково-методологічні засади). На державному рівні здійснюється координація діяльності органів виконавчої влади, органів місцевого самоврядування, закладів освіти й культури, наукових установ, видавничих i правоохоронних організацій, громадських об’єднань і правозахисних організацій у сфері правової освіти. Органи центральної влади затверджують освітні програми, курси, методичні рекомендації та вказівки з питань правової освіти. Забезпечують реалізацію правоосвітньої та правовиховної діяльності на місцях органи виконавчої влади, органи місцевого самоврядування та громадські організації й об’єднання правоосвітнього спрямування. Таким чином, до організації та здійснення правовосвітньої діяльності в Україні залучені різноманітні органи влади та соціальні інститути. Однак, все ж таки, ключова роль відводиться саме освіті.

Зазначимо, що правова освіта, не виокремлюється із національної системи освіти, а є лише їі складовою та здобувається шляхом формальної (за освітніми програмами відповідно до рівнів освіти, галузей знань, спеціальностей (професій) та здобуттям кваліфікацій, що визнаються державою), неформальної (за освітніми програмами відповідно до рівнів освіти, може завершуватися присвоєнням професійних та/або часткових освітніх кваліфікацій) й інформальної освіти (самоорганізоване здобуття правоосвітніх компетентностей під час повсякденної діяльності). Здобуття правових знань здійснюється переважно в формальній освіті, що структурно представлена в Україні мережею закладів дошкільної, повної загальної середньої, позашкільної, спеціалізованої, професійної (професійно-технічної), фахової передвищої, вищої та післядипломної освіти [0]. У загальному вигляді правова освіта складається з двох підсистем:

- непрофесійної загальноправової освіти (здійснюється в закладах освіти всіх рівнів, а також як корпоративне навчання та самоосвіта громадян);

- професійної юридичної (спеціально-правової) освіти (здійснюється у профільних закладах освіти) [0;0].

Безсумнівно, існує суттєва різниця між наданням правових знань у закладах загальноосвітнього спрямування та наданням знань про право, державу та законодавство, які є фундаментальними й більш глибокими, у спеціалізованих закладах освіти правового або юридичного спрямування. Різниця полягає насамперед у кількості аудиторних і позааудиторних годин, що відводяться на викладання правових знань, а також у змістовому наповненні освітніх програм $i$ курсів. У такому разі можна розглядати систему правової освіти у широкому 
(набуття правових знань людиною від ii народження та їх удосконалюється протягом усього життя) та у вузькому розумінні (здобуття особистістю юридичної освіти та присудження відповідної кваліфікації).

Розглянемо спочатку непрофесійну загальноправову підсистему правової освіти, що здобувається здебільшого у закладах формальної освіти. Зауважимо, що, відповідно до даних Державної служби статистики України, у 2019 р. (на жаль, офіційні дані станом на лютий 2021 р. на державному рівні оприлюднені лише за 2019 р.) в країні функціонувало 31342 заклади освіти (з них: 14,8 тис. закладів дошкільної, 15,2 тис. - загальної середньої, 723 - професійної (професійно-технічної), 338 - вищої передфахової та 281 - вищої освіти), у яких навчалося 5538,8 тис. здобувачів освіти [0]. Дані наводяться без урахування тимчасово окупованої території Автономної Республіки Крим, м. Севастополя та тимчасово окупованих територій у Донецькій та Луганській областях. Отже, більш 5,5 млн. населення, переважно молоді люди, щорічно отримують у закладах освіти різних рівнів правові знання, розвивають правові й громадянські компетентності, відповідні ціннісні орієнтири, уміння й навички. На жаль, на державному рівні відсутні дані про здобуття правової освіти у закладах позашкільної, спеціальної освіти та освіти дорослих, у тому числі у післядипломній освіті. Відомо лише, що у закладах позашкільної освіти набуття правових знань здійснюється за гуманітарним напрямом.

Як було зазначено вище, система правової освіти у широкому розумінні - це набуття правових знань від народження людини та постійне їх удосконалюється протягом усього життя. Таким чином правова освіта є безперервним процесом, іiі здобуття шляхом формальної освіти починається у закладах дошкільної освіти i закінчуючи закладами післядипломної освіти (профільною спеціалізованою підготовкою, перепідготовкою, підвищенням кваліфікації, стажуванням).

Так, у закладах дошкільної освіти дітям у формі гри надаються початкові знання про норми поведінки, формуються навички їх дотримання, виховується повага до батьків, вихователів, ровесників, людей похилого віку, інвалідів та ін. Відповідно до Базового компонента дошкільної освіти (Державного стандарту дошкільної освіти) у новій редакції, відповідно до освітнього напряму «Дитина в соціумі», результатом сформованості соціально-громадянської компетентності $\epsilon$ «ціннісне ставлення дитини до себе, своїх прав і прав інших, наявність уявлень про правила і способи міжособистісної взаємодії з членами сім’ї, родини, іншими людьми та вмінь дотримуватись цих правил в соціально-громадському просторі...» [0].

3 практичного досвіду розуміємо, що сьогодні кожна людина має виховуватися в першу чергу 3 почуттям власної гідності, лише тоді можна говорити про формування самої людини. Починати цей процес потрібно саме 3 
дошкільного віку дитини. У цьому контексті О. Мельничук зазначає, що кожна дитина вимагає ставлення до себе як до найціннішої у світі істоти, тому важливо не принизити iї гідність, із тим щоб не загальмувати процес розвитку. Зараховуючи дітей до навчального закладу, батьки довіряють педагогічним працівникам особистість дитини, яка є вразливою і потребує підтримки [7]. Таким чином, моральний досвід перших років життя та добра атмосфера оточення у подальшому визначають душевний настрій дитини в отриманні моральноправових знань.

3 початковими правовими знаннями дитина приходить до загальної середньої освіти, у якій відбувається формування громадянських і соціальних компетентностей (ідеї демократії, справедливості, рівності, прав людини, добробуту, здорового способу життя, усвідомлення рівних прав і можливостей), необхідних кожній сучасній людині. Для надання правових знань здобувачам загальної середньої освіти розробляються й запроваджуються в освітньо-виховний процес відповідні навчальні програми, курси. Зокрема, у початковій школі запроваджуються елементи правової освіти, зазвичай у змісті інших предметів. У базовій та профільній середній освіті викладаються предмети правового змісту («Права дитини», «Практичне право», «Основи правознавства», «Права людини» та ін.). У закладах гуманітарного спрямування створюються класи із поглибленим вивченням правознавства або профільні класи [8].

Досліджуючи систему правознавчих дисциплін, що викладаються у закладах загальної середньої освіти, науковці вказують на деякі позитивні та негативні моменти. Зокрема, Л. Рябовол стверджує, що у викладанні правознавства якісними змінами можна вважати вдосконалення мети, змісту, підходів, актуальних у педагогіці та юриспруденції, упровадження загальнообов'язкового курсу, пропедевтичних/курсів за вибором. В той же час, негативним є те, що на вивчення курсу правової дисципліни виділено мало годин (зазвичай одна година на тиждень), що негативно позначається на якості засвоєння навчального матеріалу [9]. І. Смагін звертає увагу на те, що існують певні проблеми перед авторами нових навчальних програм, підручників та посібників із правознавчих дисциплін, що зумовлюються неузгодженістю теоретичного та прикладного спрямування цих курсів; «знаннєвого» та «компетентнісного» підходів до правової освіти школярів [10].

В цілому можна стверджувати, що узагальнена структура правової освіти в закладах загальної середньої освіти охоплює повний період навчання - від початкової до профільної середньої освіти та складається з набору обов’язкових курсів та курсів за вибором, факультативів, що свідчить про диверсифікацію освітніх програм правового спрямування. Крім того, у позаурочний i позашкільний час у школах проводяться правові тижні, гуртки та інші заходи на 
правовиховну й правознавчу тематику із запрошенням працівників правоохоронних органів, правозахисних організацій, психологічних служб тощо. Наступним етапом здобуття правової освіти шляхом формальної освіти $\epsilon$ професійна (фахова) освіта, що представлена мережею закладів професійної (професійно-технічної), фахової передвищої, вищої та післядипломної освіти. В цих закладах до викладання дисциплін правового спрямування залучаються вчені, представники правозахисних організацій, інші фахівці в галузі права. Також, як і у школах, проводяться позааудиторні заходи правоосвітнього спрямування. Втім, існує й низка проблем, серед можна відмітити такі: під час розроблення правового курсу не враховуються професійні навички, вік, соціальний статус, психологічні особливості здобувачів освіти; існує необхідність у розробленні різних за складністю курсів, орієнтованих на відповідні інтереси конкретного соціуму [11]. В. Олійник стверджує, що в правовій освіті недостатня увага приділяється проблемі формування правової компетентності керівників закладів освіти, а також відсутні методики діагностування рівня іiі сформованості у цих керівників [12]. А. Будас також вказує на низку недоліки в правовій освіті, а саме: перехід правознавства у закладах вищої освіти з нормативної у вибіркову дисципліну; відсутність достатньої кількості кваліфікованих викладачів правознавчих дисциплін; слабка забезпеченість освітнього процесу відповідною правовосвітньою науково-методичною та навчальною літературою; використання в педагогічній практиці застарілих форм i методів викладання правових дисциплін; невелика охопленість студентської молоді участю у правових проектах громадських організацій; відсутність позааудиторних засобів поширення правової інформації по телебаченню і радіо та ін. [13].

Провідне місце у системі правової освіти займає юридична (правнича) освіта, яка є самостійним складовим компонентом системи освіти. Ї̈̈ структура включає загальну середню, професійну (професійно-технічну), фахову передвищу та вищу освіту юридичного профілю, післядипломну юридичну освіту, професійну самоосвіту в галузі права.

Юридична освіта, що здобувається у закладах вищої освіти, вже давно потребує іiі модернізації. Головною проблемою, що потребує розв'язання, $\epsilon$ «невідповідність змісту юридичної освіти і якості підготовки в правничих школах сучасним вимогам ринку праці та викликам, що стоять перед сучасним демократичним суспільством, глобальним тенденціям розвитку та завданням професійної діяльності правників у різних сферах діяльності» [14].

Зазначимо, що вища юридична освіта, відповідно до переліку галузей знань i спеціальностей, за якими здійснюється підготовка здобувачів вищої освіти - в галузі знань 08 «Право» здійснюється за спеціальностями 081 «Право», 082 «Міжнародне право» [15]. Таким чином здійснюється підготовка фахівців 3 
правничої професії.

Варто відмітити, що кількість закладів вищої юридичної освіти в Україні за роки незалежності стрімко зросла - 36 у 1991 р. до майже 300 у 2010 р. [16]. Станом на 1 січня 2019 р. кількість закладів освіти, що здійснюють підготовку бакалаврів $з$ права (спеціальність 081 «Право») становила 193, магістрів - 120, молодших спеціалістів - 128, спеціалістів - 87, що склало загальну кількість здобувачів юридичної освіти - 104565 осіб, з них 64783 особи - бакалаври. Лідируючі позиції серед здобувачів вищої освіти за спеціальністю «Право» займають Національний юридичний університет ім. Ярослава Мудрого, Національний університет «Одеська юридична академія» та Київський національний університет ім. Тараса Шевченка. За спеціальністю 293 «Міжнародне право» здобувають вищу освіту 2740 осіб, з них 1884 - бакалавра (у 26 закладах освіти) та 856 - магістра (у 16 закладах освіти). Лідирують серед здобувачів освіти - Київський національний університет ім. Тараса Шевченка, Міжнародний гуманітарний університет та Національний юридичний університет ім. Ярослава Мудрого [17].

В 2015 р. вийшла в світ Біла книга 3 реформування української юридичної освіти, в якій, на підставі результатів проведених досліджень, визначено низку проблем, зокрема: відсутність єдиних стандартів (відсутність комплексного бачення змісту, мети, завдань, організаційно-правових форм освітнього процесу в правничій галузі, проблема 3 переліком спеціальностей і спеціалізацій); недосканалість навчальних планів; недостатність практичної складової; потреба у висококваліфікованих викладацьких кадрах, у тому числі які володіють європейськими мовами; недостатня орієнтація на європейське законодавство та практику; використання застарілих (радянських) конструкцій та теорій в якості доктринального підгрунтя (застаріле навчально-методичне та дидактичне забезпечення, юридична термінологія); потреба в оновленні способів викладання інформації на сторінках навчальної літератури (проблемні питання, матеріали судової практики, задачі (казуси), наукові публікації, схеми, таблиці та ін.); надмірна кількість юридичних вищих навчальних закладів (значна їх кількість $€$ непрофільними, наприклад, відкриті юридичні факультети у непрофільному закладі освіти); потреба у покращенні процедури оцінювання якості знань здобувачів освіти [18].

Звичайно, деякі перелічені проблеми стосуються не тільки юридичної вищої освіти, а є проблемою всієї системи освіти, у тому числі ії правової складової. Ключовою проблемою юридичної освіти, як і всієї системи національної професійної освіти, $є$ її невідповідність до сучасних потреб держави і суспільства, низка якість освіти. На жаль, в Україні відкинуто історично сформовану та визнану в світі практику здобуття юридичної освіти в класичних університетах, 
що спроможні підготувати висококваліфікованого спеціаліста в галузі права, здатного реалізувати себе у сферах судочинства, адвокатури, прокуратури, нотаріату, юридичних консультацій. Не вистачає таких спеціалістів і в закладах освіти інших рівнів як у формальній, так i неформальній освіті, які здатні здійснювати правоосвітньою діяльністю з метою підвищення правової культури та правової свідомості громадян країни.

Висновки. Підсумовуючи слід зазначити, що в Україні функціонує цілісна система правової освіти, яка $\epsilon$ складною, багатоаспектною системою, має множину взаємопов'язаних, взаємозалежних та взаємодіючих елементів Ключову роль в організації правоосвітньої діяльності відіграють органи державної влади, які забезпечують функціонування i розвиток інституціональної мережі, де громадяни країни здобувають знання і навички 3 правової освіти.

В Україні здобуття правової освіти здійснюється шляхом формальної, неформальної й інформальної освіти, розраховано в першу чергу на молоде покоління та передбачає істотну трансформацію світоглядних орієнтацій, самосвідомості людини та формування в неї громадянських цінностей. Наймасовішим $є$ здобуття правових знань шляхом формальної освіти через існуючу мережу закладів освіти різних рівнів, починаючи 3 дошкільного віку людини і закінчуючи освітою дорослих. У загальному вигляді правова освіта складається 3 двох підсистем - непрофесійної загальноправової та професійної юридичної (спеціально-правової) освіти. Також систему правової освіти можна розглядати як у широкому (набуття правових знань людиною від їі народження та їх удосконалюється протягом усього життя), так і у вузькому розумінні (здобуття особистістю юридичної освіти та присудження відповідної кваліфікації).

Сучасна система правової освіти має низку проблем, які потребують розв'язання на державному рівні, зокрема, непослідовність у розробленні та здійсненні освітньої політики щодо поширення правових знань серед населення; перегляд, уточнення та/або оновлення змісту правової освіти, програм, правових дисциплін; відсутність узгодження в питаннях упровадження навчальних програм (курсів) на всіх рівнях освіти для всіх вікових груп населення; відсутність системності в підготовці/перепідготовці педагогічних i науково-педагогічних кадрів, задіяних у поширенні правових знань; здійснення моніторингу якості та результатів надання правових знань; реформування юридичної вищої освіти та ін. Серед перспективних напрямів подальших досліджень пріоритетними є розробка механізмів публічного управління правовою освітою в Україні.

\section{Лimepamypa:}

1. Про Національну програму правової освіти населення [Електронний ресурс] : Указ Президента України № 992/2001 від 18 жовтня 2001 p. - Режим доступу : https://zakon. 
rada.gov.ua/laws/show/992/2001\#Text.

2. Про освіту [Електронний ресурс] : Закон України від 05 вересня 2017 р. № 2145-VIII [iз змін. та доп.] : за станом на 01 січ. 2021 p. - Режим доступу : https://zakon.rada.gov.ua/ laws/show/2145-19\#Text.

3. Висоцька Л. В. Формування змісту правової освіти учнівської молоді в Україні (друга половина XX - початок XXI століття) : дис. ... канд. пед. наук : 13.00 .01 / Л. В. Висоцька. Кривий Ріг, 2017. - 310 с.

4. Чудинов О. Р. Правове образование в инженерно-техническом вузе / О. Р. Чудинов // Ученые записки Орловского государственного университета. - 2013. - № 5 (55). - С. 201-205.

5. Статистична інформація. Демографічна та соціальна статистика. Освіта : офіційний сайт Державної служби статистики України. - Режим доступу : http://www.ukrstat.gov.ua/.

6. Про затвердження Базового компонента дошкільної освіти (Державного стандарту дошкільної освіти) нова редакція [Електронний ресурс] : наказ Міністерства освіти і науки України від 12.01.2021 p. № 33. - Режим доступу : $\mathrm{https://mon.gov.ua/}$ storage/app/media/rizne/2021/12.01/Pro_ novu_redaktsiyu\%20Bazovoho\%20komponenta\%20doshkilnoyi\%20osvity.pdf.

7. Мельничук О. Ф. Конституційно-правове забезпечення права на освіту в Україні в контексті європейського досвіду : дис. ... д-ра юрид. наук : спец. 12.00.02 / О. Ф. Мельничук. К., 2015. - С. 141.

8. Полякова О. С. Публічне управління правовою освітою населення в Україні : монографія / О. С. Полякова. - Х. : Вид-во ХарРІ НАДУ «Магістр», 2018. - С. 189.

9. Рябовол Л. Т. Система навчання правознавства учнів основної і старшої школи : дис. ... д-ра пед. наук : 13.00.02 / Л. Т. Рябовол. - К., 2015. - 600 с.

10. Смагін I. I. «Правознавчий» та «законодавчий» підходи до викладання шкільних правових навчальних предметів / I. І. Смагін // Вісник Житомирського державного університету. - 2008. - Вип. 42. - С. 51.

11. Polyakova O. Analysis of the legal education system functioning in Ukrainian educational institutions: public and administrative aspect / O. Polyakova // Association agreement: from partnership to cooperation (collective monograph) ; edited by Maryna Dei, Olha Rudenko. Hamilton, Ontario: Accent Graphics Communications \& Publishing, 2018. - P. 131.

12. Олійник В. В. Формування правової компетентності керівників навчальних закладів у системі післядипломної педагогічної освіти : автореф. дис. ... канд. пед. наук : спец. 13.00.04 «Теорія та методика професійної освіти» / В. В. Олійник. - Запоріжжя, 2008. - С. 17.

13. Будас А. П. Становлення та розвиток правової освіти в Україні: історикопедагогічний аспект / А. П. Будас // Сучасні інформаційні технології та інноваційні методики навчання у підготовці фахівців: методологія, теорія, досвід, проблеми. - 2010. - Вип. 26. C. 196-197.

14. Концепція розвитку юридичної освіти (проект) [Електронний ресурс] : офіційний веб-сайт Міністерства освіти і науки України. - Режим доступу : https://mon.gov.ua/ua/osvita/ visha-osvita/koncepciya-vdoskonalennya-pravnichoyi-yuridichnoyi-osviti-dlya-fahovoyi-pidgotovkipravnika.

15. Про затвердження переліку галузей знань і спеціальностей, за якими здійснюється підготовка здобувачів вищої освіти [Електронний ресурс] : постанова Кабінету Міністрів України № 266 від 29 квітня 2015 р. : за станом на 11 лют. 2017 р. - Режим доступу : https://zakon.rada.gov.ua/laws/ show/266-2015-\%D0\%BF\#Text. 
16. Стан юридичної освіти та науки в Україні (результати дослідження) [Електронний peсурс] / Координатор проектів ОБСЄ в Україні ; Нац. ун-т «Києво-Могилянська академія». Київ, 2009-2010. - Режим доступу : http://www.osce.org/uk/ ukraine/108309?download=true.

17. Стан юридичної освіти [Електронний ресурс] : Міністерство юстиції України. Київ, 2019. - Режим доступу : https://minjust.gov.ua/files/ general/2019/03/18/20190318171622-46.pdf.

18. Біла книга 3 реформування української юридичної освіти (за матеріалами міжнародної науково-практичної конференції «Свропеїзація української юридичної освіти: німецько-український досвід» / Київ, 21 і 22 листопада 2014 ; Федеральне міністерство освіти і науки Федеративної Республіки Німеччина; Університет ім. Георга Августам. Геттінгена, юридичний факультет ; Київ. нац. ун-т ім. Т. Шевченка, юридичний факультет ; Центр німецького права ; Німецько-український правознавчий діалог / упоряд. : Р. Мельник, О. Шаблій, . Шлоер. - К. : Корпорація «Науковий парк Київський університет ім. Т. Шевченка»; Панов, 2015. -С. 18-36.

\section{References:}

1. Pro Natsionalnu prohramu pravovoi osvity naselennia : Ukaz Prezydenta Ukrainy № 992/2001 vid 18 zhovtnia 2001 r. (n.d.). zakon.rada.gov.ua. Retrieved from https://zakon.rada.gov.ua/laws/show/992/2001\#Text [in Ukrainian].

2. Pro osvitu : Zakon Ukrainy vid 05 veresnia 2017 r. № 2145-VIII [The Law of Ukraine «On the education»]. (n.d.). zakon.rada.gov.ua. Retrieved from https://zakon.rada.gov.ua/ laws/show/2145-19\#Text [in Ukrainian].

3. Vysotska, L.V. (2017). Formuvannia zmistu pravovoi osvity uchnivskoi molodi v Ukraini (druha polovyna XX - pochatok XXI stolittia). Candidate's thesis. Kryvyi Rih. [in Ukrainian].

4. Chudynov, O.R. (2013). Pravove obrazovanye v ynzhenerno-tekhnycheskom vuze. Uchenble zapysky Orlovskoho hosudarstvennoho unyversyteta, 5 (55), 201-205 [in Russian].

5. Statystychna informatsiia. Demohrafichna ta sotsialna statystyka. Osvita : ofitsiinyi sait Derzhavnoi sluzhby statystyky Ukrainy. (n.d.). ukrstat.gov.ua. Retrieved from http://www.ukrstat.gov.ua/ [in Ukrainian].

6. Pro zatverdzhennia Bazovoho komponenta doshkilnoi osvity (Derzhavnoho standartu doshkilnoi osvity) nova redaktsiia : nakaz Ministerstva osvity i nauky Ukrainy vid 12.01.2021 r. № 33. (n.d.). mon.gov.ua. Retrieved from https://mon.gov.ua/storage/app/media/rizne/2021/12.01/Pro_novu_ redaktsiyu\%20Bazovoho\%20komponenta\%20doshkilnoyi\%20osvity.pdf [in Ukrainian].

7. Melnychuk, O.F. (2015). Konstytutsiino-pravove zabezpechennia prava na osvitu v Ukraini v konteksti yevropeiskoho dosvidu. Doctor's thesis. Kyiv [in Ukrainian].

8. Poliakova, O.S. (2018). Publichne upravlinnia pravovoiu osvitoiu naselennia $v$ Ukraini : monohrafiia. Kharkiv : Vyd-vo KharRI NADU «Mahistr» [in Ukrainian].

9. Riabovol, L.T. (2015). Systema navchannia pravoznavstva uchniv osnovnoi i starshoi shkoly. Doctor's thesis. Kyiv [in Ukrainian].

10. Smahin, I.I. (2008). «Pravoznavchyi» ta «zakonodavchyi» pidkhody do vykladannia shkilnykh pravovykh navchalnykh predmetiv. Visnyk Zhytomyrskoho derzhavnoho universytetu, 42, 51 [in Ukrainian].

11. Polyakova, O. (2018). Analysis of the legal education system functioning in Ukrainian educational institutions: public and administrative aspect. Association agreement: from partnership to cooperation (collective monograph) ; edited by Maryna Dei, Olha Rudenko. Hamilton, Ontario: Accent Graphics Communications \& Publishing [in Canada]. 
12. Oliinyk, V.V. (2008). Formuvannia pravovoi kompetentnosti kerivnykiv navchalnykh zakladiv u systemi pisliadyplomnoi pedahohichnoi osvity. Extended abstract of candidate's thesis. Zaporizhzhia [in Ukrainian].

13. Budas, A.P. (2010). Stanovlennia ta rozvytok pravovoi osvity v Ukraini: istorykopedahohichnyi aspekt. Suchasni informatsiini tekhnolohii ta innovatsiini metodyky navchannia $u$ pidhotovtsi fakhivtsiv: metodolohiia, teoriia, dosvid, problemy, 26 [in Ukrainian].

14. Kontseptsiia rozvytku yurydychnoi osvity (proekt) : ofitsiinyi veb-sait Ministerstva osvity i nauky Ukrainy. (n.d.). mon.gov.ua. Retrieved from https://mon.gov.ua/ua/osvita/vishaosvita/koncepciya-vdoskonalennya-ravnichoyi-yuridichnoyi-osviti-dlya-fahovoyi-pidgotovki-pravnika [in Ukrainian].

15. Pro zatverdzhennia pereliku haluzei znan i spetsialnostei, za yakymy zdiisniuietsia pidhotovka zdobuvachiv vyshchoi osvity : postanova Kabinetu Ministriv Ukrainy № 266 vid 29 kvitnia 2015 r. : za stanom na 11 liut. 2017 r. (n.d.). zakon.rada.gov.ua. Retrieved from https://zakon.rada.gov.ua/laws/show/ 266-2015-\%D0\%BF\#Text [in Ukrainian].

16. Stan yurydychnoi osvity ta nauky v Ukraini (rezultaty doslidzhennia) / Koordynator proektiv OBSIe v Ukraini ; Nats. un-t «Kyievo-Mohylianska akademiia». Kyiv, 2009-2010. (n.d.). osce.org. Retrieved from http://www.osce.org /uk/ ukraine/108309?download=true [in Ukrainian].

17. Stan yurydychnoi osvity : Ministerstvo yustytsii Ukrainy. Kyiv, 2019. (n.d.). minjust.gov.ua. Retrieved from https:/minjust.gov.ua/files/general/2019/03/ 18/2019031817162246.pdf [in Ukrainian].

18. Bila knyha $\mathrm{z}$ reformuvannia ukrainskoi yurydychnoi osvity (za materialamy mizhnarodnoi naukovo-praktychnoi konferentsii «Ievropeizatsiia ukrainskoi yurydychnoi osvity: nimetsko-ukrainskyi dosvid» (2015). / Kyiv, 21 i 22 lystopada 2014 ; Federalne ministerstvo osvity i nauky Federatyvnoi Respubliky Nimechchyna; Universytet im. Georga Avgustam. Gettingena, yurydychnyi fakultet; Kyiv. nats. un-t im. T. Shevchenka, yurydychnyi fakultet ; Tsentr nimetskoho prava ; Nimetsko-ukrainskyi pravoznavchyi dialoh / uporiad.: R. Melnyk, O. Shablii, B. Shloer. Kyiv : Korporatsiia «Naukovyi park Kyivskyi universytet im. T. Shevchenka»; Panov, 18-36 [in Ukrainian]. 